\title{
A Model for settlement of health insurance organizations' debt to health service delivery institutions
}

\author{
Masood Abolhallaj ${ }^{1}$, Seyed Mohammadreza Hosseini ${ }^{2 *}$, Mehdi Jafari $^{3}$, Fatemeh Alaei ${ }^{4}$
}

Received: 13 Mar 2017

Published: 16 Dec 2017

\begin{abstract}
Background: Sukuk is a type of financial instrument backed by balance sheet and physical assets. This applied and descriptive study aimed at providing solutions to the problems faced by insurance companies in the health sector.

Methods: In this study, we achieved operational models by reviewing the release nature and mechanism of any of the securities and combining them.

Results: According to the model presented in this study, 2 problems could be solved: settling the past debts and avoiding future debts. This model was deigned based on asset backed securities.

Conclusion: Utilizing financing instruments (such as Sukuk), creating investment funds, and finding a solution to this problem, this study was conducted in 2 aspects: (1) models that are settling old debts of the organization, and (2) models that prevent debts in the future.
\end{abstract}

Keywords: Health insurance, Organization's debt, Service delivery

Copyright $@$ Iran University of Medical Sciences

Cite this article as: Abolhallaj M, Hosseini SM, Jafari M, Alaei F. A Model for settlement of health insurance organizations' debt to health service delivery institutions. Med J Islam Repub Iran. 2017 (16 Dec);31:89. https://doi.org/10.18869/mjiri.31.89

\section{Introduction}

Health systems not only play an important role in improving health, but also are responsible for protecting individuals against the financial costs of illnesses and diseases (1). World health organization (WHO) emphasized fair financial contribution as one of the 3 fundamental goals of health systems. The main aim of financial protection is to ensure that every member of the society has equal access to healthcare services $(2,3)$.

Due to the rapid increase of healthcare costs compared to incomes in many countries, the health sector is faced with many financing problems (4). Without an appropriate finance system, only a limited number of population would have timely access to health services. In fact, financing a health system determines whether individuals can purchase the services or whether the services are available when they are needed (5). In general, different countries use one or more of the 4 main methods of health

Corresponding author: Seyed Mohammadreza Hosseini, mhoseini67@yahoo.com

1. Budgeting and Performance Monitoring Center, Ministry of Health and Medical Education, Tehran, Iran

2. Faculty of Management, Tehran University, Tehran, Iran, \& Deputy of Department of Finance and Economic Affairs (Avapezeshk Holding), Tehran, Iran.

3. Department of Health Services Management, School of Health Management and Information Sciences, Iran University of Medical Sciences, Tehran, Iran, \& Health Management and Economics Research Center, Iran University of Medical Sciences, Tehran, Iran.

4. Faculty of Management, Tehran University, Tehran, Iran, \& Senior of Department of Finance and Economic Affairs (Avapezeshk Holding), Tehran, Iran. systems financing, which are as follow: (1) tax-based systems, (2) out-of-pocket payments, (3) social health insurance, (4) private insurance programs (6). These methods have affected the functional indices of the system, such as equity. Therefore, during the final decades of the 20th century, health researchers have come to realize the necessity of introducing and using new instruments to assess and investigate equity in healthcare financing (7).

Financing has created some problems for individuals in the costs of using health services. Some of the consequences of governing unfair conditions in the health system include degradation of welfare qualifications by providing access to healthcare costs, reduction in national production in the wake of reduction of savings, and its allocation to treatment costs, and thus pushing people under the poverty line due to catastrophic healthcare costs (8). On the other hand, methods of insurance companies

$\uparrow$ What is "already known" in this topic:

14 types of Sukuk have been designed that among these the lease Sukuk has mostly used in the world.

$\rightarrow$ What this article adds:

Provide a model for resolving the debt of the health insurance organization to health care providers. 
were changed from reimbursement of costs spent for patient care in hospitals into separated reimbursement systems. Hence, hospitals try to be active within the scope of each patient's financial ability, which is very similar to commercial activities of organizations that try to operate in accordance with the budget of each project (9).

Ministry of Health and Medical Education as a health proctor in Iran has begun conducting health-related studies considering the Fifth Development Plan of implementing health reform program in 2014 and taking into account the general duties, missions, and upstream documents, especially the 20-year vision document, and general health policies notified by the Supreme Leader. The transformation of health system is executed with 3 approaches; namely, financial protection of people, equity in access to health services, and improving quality of services to understand the expected objectives and improvements in our health system.

In this project, a health insurance organization was formed to realize the unification of the insurer units. The main securement source of this organization was from central government funds, annual budget of the Ministry of Health and Medical Education, and insurance premiums. According to the Act enacted by the parliament and legal frameworks, it is anticipated that the sources be obtained from decreasing the subsidies and the value added tax (VAT) sources, as government resources have to be allocated to health system reform plan.

In recent years, coinciding with the reform plan, economic challenges of the country (budget deficits, difficulty in oil sales, oil price fluctuations, etc.) prevented the full implementation of the reform plan in such a way that cessation of receiving the budget approved by health insurance created a huge debt for health centers in the country. Therefore, it is anticipated that the existing debt will increase, unless the problems are solved. In 2015, debt levels of the organization with a $50 \%$ growth rate have reached to 80000 billion Rials, which increased to 120 000 billion Rials in 2016, with a growth rate of $70 \%$ (10).

The literature indicates that Islamic financial system is a network of financial instruments, markets, and institutions that has the task of allocating resources based on the Islam principles. The Islamic financial system fairly defines the relationship between economic institutions, and its main purpose is capital utilization to achieve efficiency and avoid the hoarding of capital resources. One of the most important sectors of the Islamic financial system is the services and financial instruments that have been developed over time.

In recent years, the use of a new tool called Sukuk has been the focus of attention by Islamic countries, which can be classified among the securities, and plays an important role in absorbing liquidity, enforcing monetary and fiscal policies, and budget deficit of the government (11).

Sukuk is a type of financial instrument backed by balance sheet and physical assets. The companies demanding issuance of Sukuk are the applicants for borrowing based on their physical assets, and on the other hand, lenders and investors attempt to grant loans based on the company's physical assets. To date, 14 types of Sukuk have been designed, among which the 'lease Sukuk' has been mostly used worldwide (12). From 2006 to the end of 2014, 607 billion dollars of Sukuk papers have been issued, and the largest volume has been related to Malaysia, UAE, Indonesia, and Bahrain (13).

Definition of Sukuk (Islamic bonds) is Islamic bonds structured in such a way that generates returns to investors without infringing Islamic law, which prohibits interest 'riba'. Sukuk represents undivided shares in the ownership of tangible assets relating to particular projects or special investment activity (14).

With regard to issuance of the first Sukuk papers in March 2011 (the first 3 months of 2011) in Iran, which was made possible by the efforts of Novin investment bank and the guarantee of Eghtesad Novin bank for financing Mahan Air company for 291500 million Rials, Sukuk market prospered in Iran like other Islamic countries.

According to the latest information, Sukuk volume issued in Iran in 2015 has been equal to 7270 billion Rials and 960 billion Tomans in the first quarter of 2016. The greatest type of issued Sukuk has been related to lease bonds and Murabaha bonds.

In this study, by taking advantage of Islamic bonds, it has been tried to provide a model for settlement of health insurance organizations' debt to health centers.

\section{Methods}

This applied and descriptive study aimed at providing solutions to the problems that insurance companies face in the health sector.

The research includes the following steps:

1. Analysis of documents (books: Rules and Regulations of the Securities Market, Introduction to Islamic Capital Market, Islamic Financial Instruments, etc.)

2. The literature review and library study in the field of internal and external experiences

3. Identification of release processes and operation of mechanisms in accordance with existing legislation; in this regard, interviews have been conducted with experts in the field.

Therefore, in this study, by reviewing the release nature and mechanism of any of the securities and combining them, we achieved operational models that have the ability to run, and by employing them, we can resolve the related problems in the research.

\section{Results}

The following model tried to solve 2 problems: settling the past debts, and preventing future debts (Figure 1).

This model was deigned based on asset backed securities. The purpose of publishing asset backed securities is to provide a financial support for asset purchase for an active economic firm in the real section of economy. In this process, the publisher (intermediate) buys the intended asset on behalf of the investors, who have bought the publisher's securities, and then leases (ordinary or conveyancing) to the sponsor (Health Fund). The sponsor commits to pay the asset payment in determined usance 


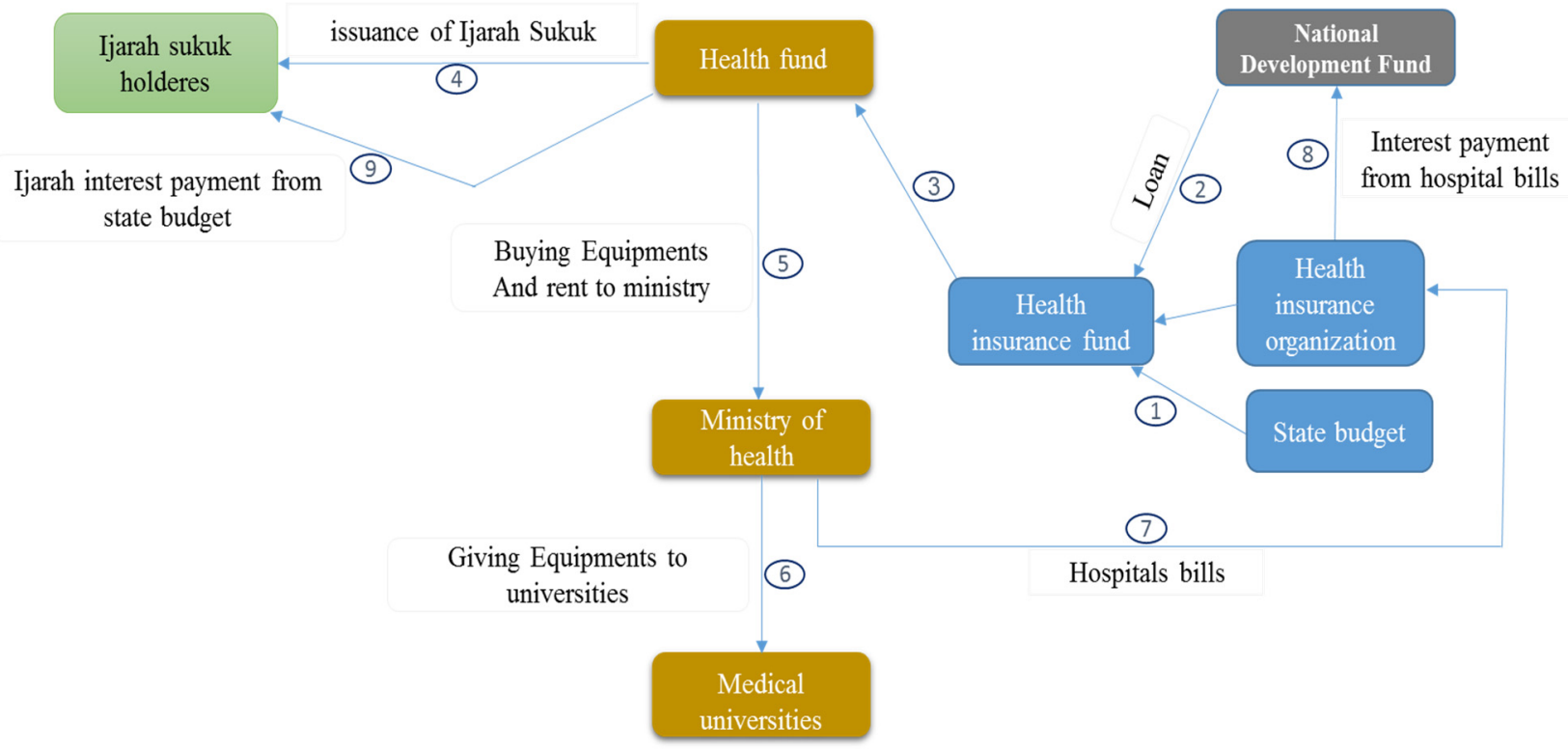

Fig. 1. Model for settlement of health insurance organizations' debt

through providing the capital for security owners.

The publisher (intermediate) convoys the asset at the end of the contract, which is called conveyancing.

The securities owners can keep the securities until the usance and benefit from its profits, or they can sell them in the secondary market.

In this model, the health insurance organization takes the necessary actions to establish a fund as "health insurance fund". The fund resources are provided from the National Development Fund loans and payments from the state budget (budget surplus to fund of healthcare reform plan, which has been approved for the settlement of past debts of health insurance). Units of the fund will be transferred to the health funds for past debt settlement. Also, the health fund tries to collect funds through the capital market. Through the issuance of Ijarah Sukuk, the fund buys the equipment and lets the equipment to the Ministry of Health through the above sources. Subsequently, Ministry of Health provides this equipment to medical universities. Health insurance payments will be inserted in hospital bills from the fund related to the use of services of medical centers by applicants, and the loan installments derived from the National Development Fund will be paid from the cash flow. Moreover, according to negotiations, predetermined budget by the government has been allocated to the health funds, so that the funds can pay principle and profit from issuing Ijarah Sukuk.

\section{Discussion}

All activities that are performed to maintain or restore health in the community and the public, including early prevention and control of hazards to treat diseases and risk management, are considered as health services and subset of the country's health system.

In the first step, the health system must be responsive to the expectations and needs of the public and have a plan to improve health. In the meantime, the financing costs of the health system are highly important. Because the need for health services is considered indispensable and vital to people, any delays in providing the services or financing them can cause irreversible damages.

Financing the health system in Iran can be done by combining several methods, meaning that the public resources of the state and the compulsory participation in the payment of premium to insurance organizations and companies mainly provide social insurance and basic health services. Iran's economic structure is such that the most important variable in the public sector and finance is petroleum revenues. Thus, the instability in the price of petroleum can result in problems for the health system.

\section{Conclusion}

Because macroeconomic problems are raised with the implementation of the health sector development plan, it will simultaneously interfere with the funds received under the plan. Therefore, single health insurance organization, which was one of the goals of this plan, faced with heavy debts to medical centers. In this study, using financing instruments, such as Sukuk, creating investment funds, and finding a solution to this problem were done in 2 aspects: models that are settling old debts of the organization, and models which prevent the debts in the future.

\section{Acknowledgement}

The authors express their appreciation to all those who helped in the implementation and completion of the study.

\section{Conflict of Interests}

The authors declare that they have no competing interests. 
References

1. Aboutorabi A, Ghiasipour M, Rezapour A, Pourreza A, Asiabar AS, Tanoomand A. Factors affecting the informal payments in public and teaching hospitals. Med J Islam Repub Iran. 2016;30:315.

2. Jia L, Yuan B, Huang F, Lu Y, Garner P, Meng Q. Strategies for expanding health insurance coverage in vulnerable populations. The Cochrane Library. 2014 Jan 1.

3. Asante AD, Price J, Hayen A, Irava W, Martins J, Guinness L, et al. Assessment of equity in healthcare financing in Fiji and Timor-Leste: a study protocol. BMJ Open. 2014 Dec 1;4(12):e006806.

4. Nabilou B, Yusefzadeh H, Rezapour A, Azar FE, Safi PS, Asiabar AS, et al. The productivity and its barriers in public hospitals: case study of ran. Med J Islam Repub Iran. 2016;30:316.

5. World Health Organization. Increasing access to health workers in remote and rural areas through improved retention: global policy recommendations. World Health Organization; 2010.

6. Gottret PE, Schieber G. Health financing revisited: a practitioner's guide. World Bank Publications; 2006.

7. Gottschalk P, Wolfe B, Haveman R. Health care financing in the US, UK and Netherlands: Distributional consequences. University of Wisconsin--Madison, Institute for Research on Poverty; 1989.

8. WHO Fairness of financial contribution methodology, Geneva: WHO; 2002

9. Jafari M, Bastani P, Ibrahimipour H, Dehnavieh R. Attitude of health information system managers and officials of the hospitals regarding the role of information technology in reengineering the business procedures: A qualitative study. Health MED. 2012 Jan 1;6(1):208-15.

10. Deputy-of-Management-Development-and-Resources. Performance Report of Budget and Performance Monitoring Center. Tehran: Ministry of Health and Medical Education; 2016.

11. Sukuk Report, 2016, "A Comprehensive Study of the Global Sukuk Market", IIFM Sukuk Report, Available at www.IIFM.net

12. Sukuk.com, global home of the sukuk industry.issued sukuk profiles.

13. Website of Iranian FARA Bourse .http://www.ifb.ir

14. http://lexicon.ft.com/Term?term=sukuk-(Islamic-bonds) 